\title{
AN INSIGHT ON ALGAL CELL DISRUPTION FOR BIODIESEL PRODUCTION
}

\author{
AARTHY A, SMITA KUMARI, PRACHI TURKAR, SANGEETHA SUBRAMANIAN*
}

Department of Biotechnology, School of Bio Sciences and Technology, VIT University, Vellore - 632 014, Tamil Nadu, India. Email: Sangeethasubramanian@vit.ac.in

Received: 13 September 2017, Revised and Accepted: 30 October 2017

ABSTRACT

Objective: This review article deals with the effect that various cell disruption techniques have on the efficiency of lipid extraction. We have reviewed existing algal cell disruption techniques that aid the biodiesel production process.

Methods: Current rise in demand for energy has led the researcher to focus on the production of sustainable fuels, among which biodiesel has received greater attention. This is due to its larger lipid content, higher growth rate, larger biomass production, and lower land use. Extraction of lipid from algae (micro and macro) for the production of biodiesel involves numerous downstream processing steps, of which cell wall disruption is a crucial step. Bead milling, high-pressure homogenization, ultra-sonication, freeze-drying, acid treatment, and enzymatic lysis are some methods of cell disruption. The cell disruption technique needs to be optimized based on the structure and biochemical composition of algae.

Result: The lipid extraction efficiency varies depending on the algal species and the cell disruption technique used.

Conclusion: In-depth research and development of new techniques are required to further enhance the cell disruption of the algal cell wall for the enhanced recovery of lipids. In addition, the operating costs and energy consumption should also be optimized for the cost-effective recovery.

Keywords: Biodiesel, Cell disruption, Microalgae, Macroalgae.

(C) 2018 The Authors. Published by Innovare Academic Sciences Pvt Ltd. This is an open access article under the CC BY license (http://creativecommons. org/licenses/by/4. 0/) DOI: http://dx.doi.org/10.22159/ajpcr.2018.v11i2.22481

\section{INTRODUCTION}

Dependence on fossil fuels for energy production is now diminishing due to its rapid depletion and emission of environmentally toxic gases. For economic and environmental sustainability, it is necessary to explore alternative carbon neutral and renewable fuel [1]. Biodiesel is one among such sustainable source and carbon neutral fuel substitute for fossil fuels. Conventional sources for biodiesel production such as oil reserve crops, animal fat, and other sources cannot satisfy the increasing demand for fuels [2]. According to many reports, waste cooking oil and algae could be the promising feasible sources for the production of biodiesel to meet the worldwide energy demand [3].

Algae are capable of producing high quantity of lipid which can be used for biodiesel production [4]. Culturing of algae near to saline or brackish water region can minimize the use of land and water [5]. Algae help in reduction of carbon dioxide emissions by converting them into glucose. This glucose is converted to fatty acids for the synthesis of membrane [6]. Under stress conditions, this fatty acid is converted into lipids which can be used for production of biodiesel. Several algal species produce different types of lipids, hydrocarbons, and other complex oils. The total oil productivity, i.e., the total mass of oil that is produced per unit volume per day depends on the oil content in the biomass and growth rate of algae [7]. The growth rate of microalgae and macroalgae differs from each other. Extensive research is being carried out on macroalgae as they contain novel lipids and fatty acids. Jeong et al. have studied the efficiency of different pretreatment technique for the extraction of lipids from macroalgae. Effect of $\mathrm{pH}$ on disruption efficiency was studied on various macroalgae such as Ulva rigida, Polysiphonia strictissima, Enteromorpha intestinalis, and Porphyra species [8]. In general, the cell wall of algae is thick and composed of fibrillar matrix and crystalline polymers which cause hindrance in the extraction process of lipids. Its composition differs from each other, and hence, different disruption methods need to be developed. For example, the cell wall of Chlorella vulgaris predominantly consists of saccharides and hemicellulose for which grinding using liquid nitrogen has shown significant results [9]. The choice of the cell disruption technique depends on the type of algae, its cell wall structure, and composition. Hence, in this review, we have discussed about the algal cell wall structure, summarized on biodiesel production technique, and detailed on cell wall disruption methods.

\section{ALGAL CELL WALL STRUCTURE}

Algal cell wall is similar to that of plant cell wall and is generally trilaminar. An organized microfibrillar structure is embedded in a continuous matrix [10]. It consists of high protein content compared to plant cell wall, with major portion constituted of glycoprotein. $45 \%$ of the cell wall is made of cellulose, also containing other carbohydrates such as hemicellulose, and limited quantities of fructose, rhamnose, and glucose. It also has algaenan, which is a resistant biopolymer. Figs. 1 and 2 represent algal spore cell wall and algal gelatinous cell wall composition, respectively. Based upon the composition of the cell wall, disruption technique is experimented. Algae produce a large quantity of oil, especially under stress and store it in between cell wall and membrane of the cell. The oil yield of algal cells varies from species to species.

\section{PROCESS OF BIODIESEL PRODUCTION}

Conversion of wet algal biomass into combustible fuel is a challenging process. Once the algal biomass is harvested, the processing of biomass takes place in various steps. Figs. 3 and 4 represent lipid content in various macroalgae and microalgae species. For extraction of energyrich compounds (triglycerides), it is first dehydrated and then made to react with a solvent like hexane. The extracted triglyceride is reacted with methanol in the presence of catalyst in a reaction known as alcoholysis or transesterification to produce glycerol and biodiesel [11]. The following chemical reaction depicts transesterification reaction of lipids present in algae for biodiesel production $[12,13]$. 


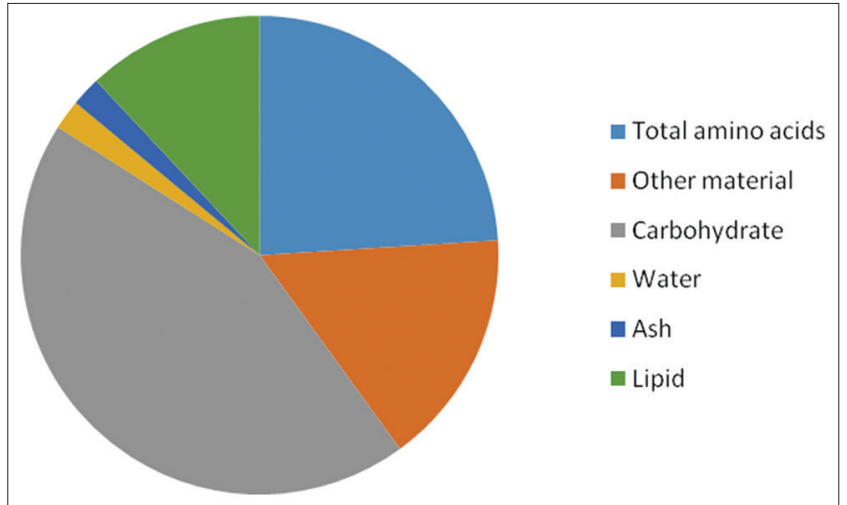

Fig. 1: Pie chart representing chemical composition of algal spore cell wall

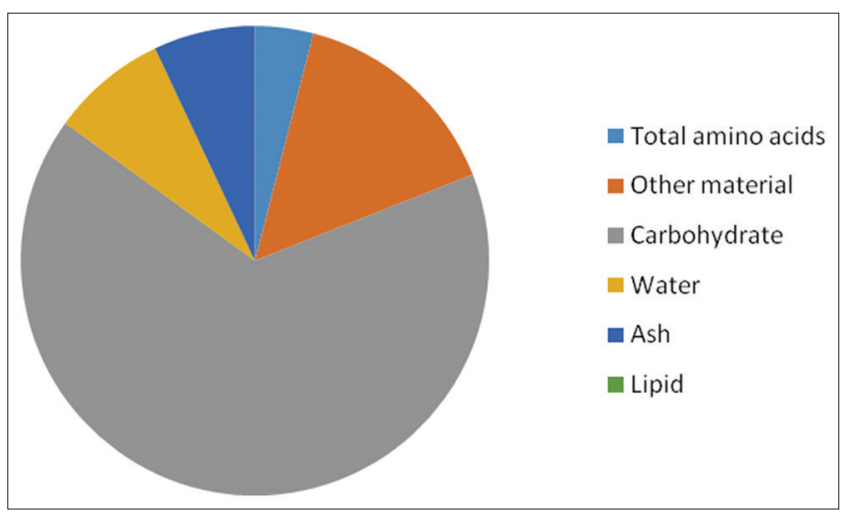

Fig. 2: Pie chart representing chemical composition of algal gelatinous cell wall

\section{TRIGLYCERIDES+METHANOL+KOH=GLYCEROL+METHYL ESTERS (BIODIESEL)}

The major steps involved in the generation of biodiesel using algae are the cultivation of algae, harvesting, lipid extraction by cell disruption, and lipid transesterification [14]. Fig. 5 represents the process of biodiesel production. Under optimal condition, green algae could double its biomass in a day with approximately $50 \%$ of lipid content $[15,16]$. The high-density biomass leads to an increase in the biodiesel production [13]. Although each one of these steps are important, cell wall disruption is particularly imperative, as the constituents of the extracted lipids are determined with respect to the disruption technique. Moreover, the challenge is microalgae are small in size and its surface is covered with a thick cell wall. The interested products are in general situated in globules or bound to cell membranes, making extraction more difficult. Hence, the use of relevant cell disruption strategy and method plays a major role in increasing the lipid extraction efficiency.

\section{ALGAL CELL WALL DISRUPTION METHODS}

A wide range of disruption methods are available for the disruption of the cell wall. They are classified into two main categories based on working mechanism which are mechanical and non-mechanical methods.

\section{MECHANICAL DISRUPTION METHODS}

Non-specific cell wall disruption is achievable by mechanical forces such as liquid-shear forces (employment of high-pressure homogenization and microfluidization), solid-shear forces (use of bead mill and highspeed homogenization), exchange of energy through waves (use of ultrasonication and microwave), electric current (application of pulsed

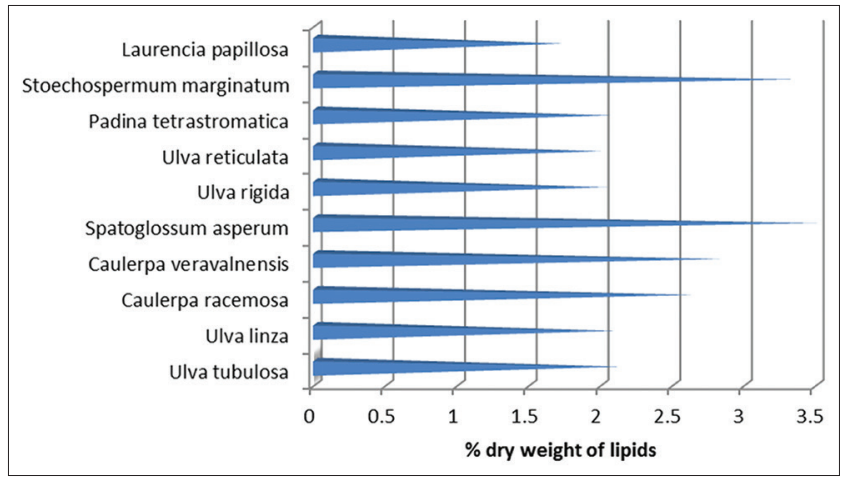

Fig. 3: Bar graph representing lipid content in various macroalgae species

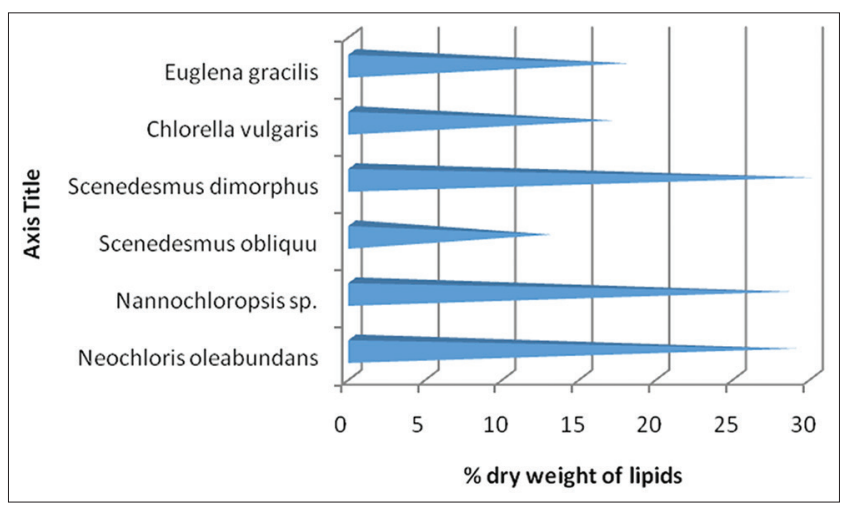

Fig. 4: Bar graph representing lipid content in various microalgae species

electric field), or heat treatment/thermolysis [17]. Table 1 summarizes the effect of different techniques on lipid extraction from various algal species. Mechanical methods have higher efficiency compared to other methods as they do not depend on the species of algae to be processed and the chances of contamination of the lipid product extracted are low [18].

\section{Bead milling}

Bead mill method includes cell wall breakdown by agitated beads. This method leads to a direct damage that is induced by the highspeed spinning of fine beads along with the biomass slurry as represented in (Fig. 6) $[19,20]$. Disruption depends mainly on the residence time of the beads in the system [21]. Other factors include bead size, cell size, and its strength [22]. Study on disruption of Chlorella vulgaris, Neochloris oleoabundans, and Tetraselmis suecica revealed that rate of release of intracellular carbohydrates and protein was higher with minimum energy consumption for smaller sized beads [23]. The rate of cell disruption is also directly proportional to volume ratio of the beads to that of cell suspension [24]. As the beads settle due to gravity, the extract could be easily removed by pipetting [25]. This technique is generally performed under laboratory scale. For large scale purposes, a dyno-mill is used, which has been successfully used for microalgal cell disruption. It utilizes rapidly rotating and notched discs for exciting the beads [26,27]. When biomass concentrations between 100 and $200 \mathrm{~g} / \mathrm{L}$ are used, the method is effective with energy utilization $[10,11]$. The disadvantages are up scaling the process as it requires an extensive cooling system for the prevention of thermal degradation of the product [28]. Bead milling proved to be the most efficient cell disruption technique for C. protothecoides with lipid recovery of $18.8 \%$ [29].

\section{High-pressure homogenization}

In this method, cell suspension is pumped with a high pressure. In an accelerated cellular jet, suspension is impinged on the stationary valve surface causing shear stress due to the pressure drop [15]. The 
Table 1: Effect of different cell disruption techniques on lipid extraction

\begin{tabular}{|c|c|c|c|c|}
\hline Algal species & Techniques & Conditions & Result & Reference \\
\hline \multirow[t]{3}{*}{ Scenedesmus dimorphus } & Bead milling & $1 \mathrm{~mm}$ glass beads, & $20.5 \%$ of dry weight lipid content & [29] \\
\hline & Ultrasonication & processed for $2 \mathrm{~min}$ & recovered & [29] \\
\hline & & $\begin{array}{l}100 \text { watt ultrasonic } \\
\text { processor, runtime }-2 \text { min }\end{array}$ & $21 \%$ of dry weight lipid recovery & \\
\hline \multirow[t]{5}{*}{ Chlorella sp. } & Bead milling & $3500 \mathrm{rpm}$ & $0.15 \mathrm{~g}$ lipid content per $0.5 \mathrm{~g} / \mathrm{l}$ dry weight & [55] \\
\hline & Microwave & $2450 \mathrm{MHz}$ & $0.18 \mathrm{~g}$ lipid content per $0.5 \mathrm{~g} / \mathrm{l}$ dry weight & [55] \\
\hline & Ultrasonication & $50 \mathrm{~Hz}, 15 \mathrm{~min}$ & $0.2 \mathrm{~g}$ lipid content per $0.5 \mathrm{~g} / \mathrm{l}$ dry weight & [55] \\
\hline & Enzymatic lysis - lysozyme & $5 \mathrm{mg} / \mathrm{l}, 55^{\circ}, 10 \mathrm{~h}$ & Lipid concentration was $22 \%$ of dry weight & [9] \\
\hline & Enzymatic lysis - cellulase & $5 \mathrm{mg} / \mathrm{l}, 55^{\circ}, 10 \mathrm{~h}$ & Lipid concentration was $24 \%$ of dry weight & [9] \\
\hline \multirow[t]{2}{*}{ Nannochloropsis } & Microwave & $60^{\circ} \mathrm{C}$ & $40 \%$ biodiesel yield & [72] \\
\hline & Sonication & $20 \mathrm{kHz}$ & $20 \%$ biodiesel yield & \\
\hline Botryococcus sp. MCC31 & Microwave & $\begin{array}{l}\text { More than } 100^{\circ} \mathrm{C}, 6 \mathrm{~min} \\
2450 \mathrm{MHz}\end{array}$ & $48.33 \%$ of dry weight recovered & [73] \\
\hline Ankistrodesmus falcatus & $\begin{array}{l}\text { Pulsed electric field } \\
\text { treatment }\end{array}$ & $\begin{array}{l}45 \mathrm{kV}, 360 \mathrm{~ns} 1 / \mathrm{e} \text { pulse } \\
\text { duration }\end{array}$ & Doubles the extraction efficiency of lipids & {$[74]$} \\
\hline
\end{tabular}

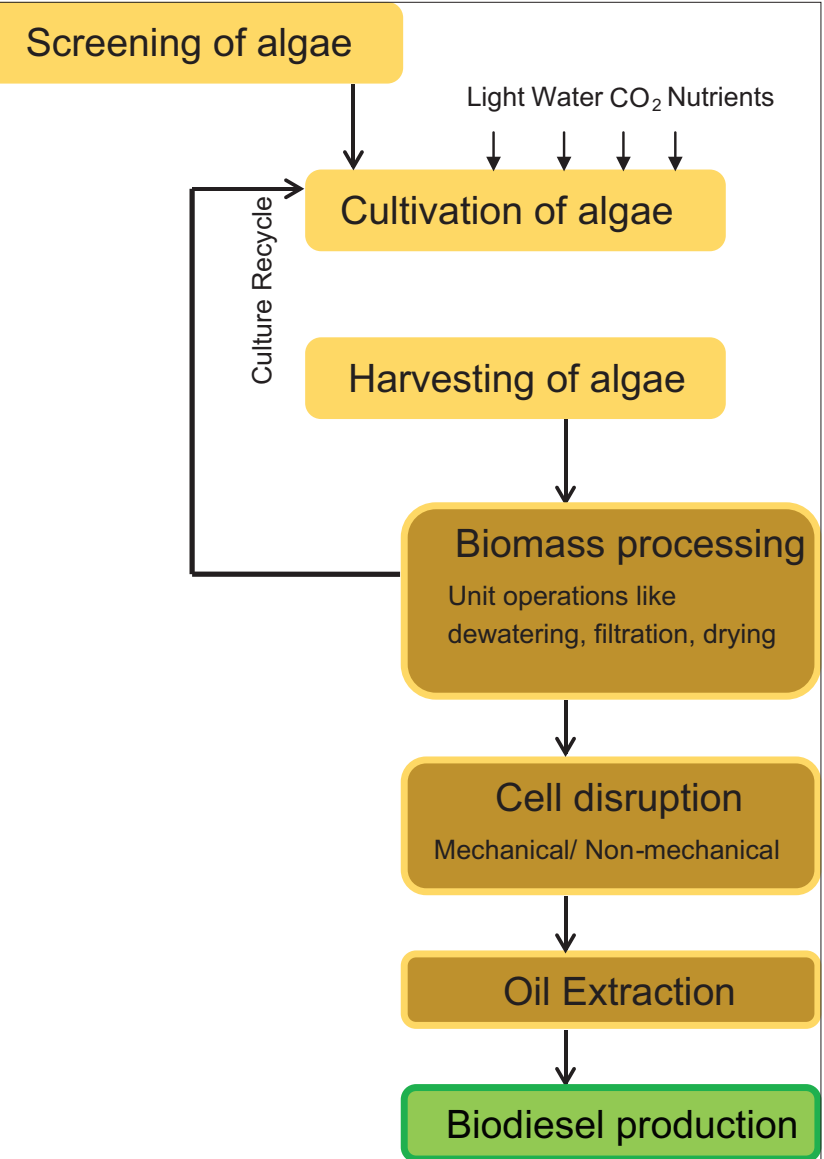

Fig. 5: Flowchart representing the process of biodiesel production

components of a high-pressure homogenization include one or more positive displacement pumps. This pump forces the suspension to an orifice and makes it collide against the valve seat. The pump works under a high pressure that ranges from $150 \mathrm{MPa}$ to $400 \mathrm{MPa}$. After the collision with the valve seat, the cells spread across its surface, followed by the collision with the impact ring. The cell disruption is caused due to the high energy densities, i.e., amount of energy released per unit volume [30]. It has been shown that high working pressure along with the number of cycles positively affects the cell disintegration [31]. The extent to which the disruption takes place depends on the pressure applied and the strength of cell wall [22]. The cell disruption can be maximized as there is a large availability of the designs of valve seat. Specific care has to be taken to minimize the damage that might be

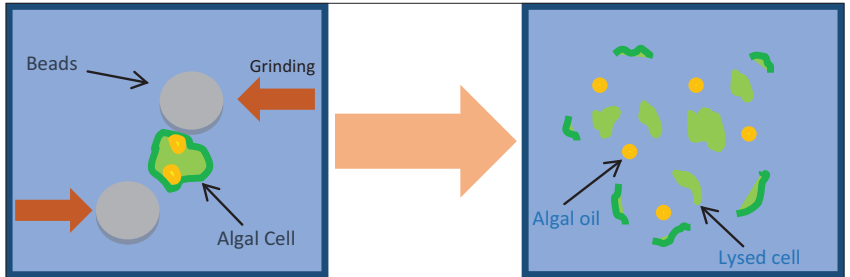

Fig. 6: Diagrammatic representation of cell disruption by bead milling

caused by the effects of cavitation [32]. This technique offers various advantages which includes lower cooling cost, lower heat formation, no dead volume in reactor, easy scale up, and low risk of thermal degradation. Although the homogenizers have many advantages, it makes the use of a large amount of energy [28]. This technique can rupture even the most hard-surfaced algae like Nannochloropsis [33] and can be utilized to process pretreated concentrated paste [34] but for application in large-scale processing, the energy consumption should be considerably low. The scale-up reduces processing capacity due to the increase in homogenizing pressure [35]. Successful disruption was achieved after the Chlorococcum cells were homogenized at a pressure of 850 bar [36]. Similarly, 8.5 times more oil was extracted using this technique from Nannochloropsis oculata [37].

\section{High-speed homogenization}

A stirring device in this instrument works at a higher revolution per minute (rpm) and comprises a stator and a rotor assembly made of stainless steel. This technique incorporates hydrodynamic cavitation that is caused due to mixing at a higher rpm and shear stress formed at the solid-liquid interphase. At the point when the critical rpm (8500) value is reached by the impeller tip, hydrodynamic cavitation is caused, which diminishes the surrounding pressure to the level of vapor pressure of the fluid. This causes the fluid to move away from the impeller. The fluid pressure is then reestablished which bring the fluid toward the impeller and that collapses the cavities. It is an easy, effective, but an aggressive technique. This method incorporates the possibility to process the suspensions with a relatively higher dry cell weight concentration $(2-6 \% \mathrm{w} / \mathrm{w})$ with the short contact time, thereby lessening the water footprint and the cost of downstream processing. Wang et al. and Balasubramanian et al. reported lipid extraction from Nannochloropsis sp. up to $76 \%$ and $38 \pm 2 \%$, respectively, using highspeed homogenization method $[38,39]$.

\section{Ultrasonication}

Ultrasonication is an alternative method to overcome the problems faced in the conventional methods. It has simple working setup conditions which gives significant purity to the product. This technique 
requires lesser time to run with higher reproducibility, operational at lower temperature, and requires overall less energy input [40].

The mechanism of cell damage includes acoustic streaming and cavitation. Once the ultrasound is applied, there is the production of microbubbles known as cavitation, which generates pressure on the cells causing them to disintegrate [41]. The mixing of the sample is facilitated by acoustic streaming [42]. The energy that is released by the high frequency waves initiates the cavitation process, and propagation of shock waves. This causes the cell disruption. Sonicators are mainly of two types, as described by Lee et al. which include the bath type and horn type. The latter makes the use of the piezoelectric generator while the former has transducers that create ultrasonic waves [43]. During the course of the treatment, there is a generation of rapid compression/decompression cycles leading to stable and transient cavitation. The transient cavitation caused by the unsteady oscillations implodes producing heat shock waves. This causes the disruption of microalgal cells, leading the cavitation to crack the membrane and the cell wall [44-46]. The collapse of bubble leads to increased mass transfer and microstreaming, aiding the increase of lipid extraction efficiency [47]. However, free radicals are produced when ultrasonication process is prolonged, decreasing the oil quality to be extracted [48]. The capability of bubble activity in cells disruption relies on ultrasound intensity, characteristics of the air bubble, and the relative nearness of the cells to the bubble [49]. Sheng et al. have reported $30 \%$ increase in yield of lipid after treatment of synechocystis PCC 6803 by ultrasonication method [50].

\section{Microwave treatment}

Microwave irradiation technique is one of the promising technologies being used in the extraction process of biodiesel production. This technique consumes less energy with high disruption efficiency and short processing time. The factors that affect the microwave-assisted extraction are dielectric properties of process mixture, process time, solid-liquid ratio, temperature, and type of solvent [51,52]. Efficient heating systems like microwave processing in combination with solvents such as hexane and ethanol can reduce the energy consumption in addition to the minimal use of solvent and is also economical. Continuous microwave systems for oil extraction from Scenedesmus obliquus were significantly affected by time and temperature. However, quality of the oil was reported high [53].

The cost of heating using a microwave is two-thirds in comparison to the conventional methods of heating. In addition, biodiesel production could also be increased using this technique. Radio frequency microwave energy provides various advantages like improvement in rate of reaction thereby leading to better separation. The use of non-contact heat source offers various advantages such as increase in energy transfer, selective heating, equipment size reduction, and quick startup. Evidently, microwave treatment could prove to be a promising technology to obtain maximum yield compared to conventional techniques [54]. It can be observed from experiments performed on Chlorella sp., Tolypothrix sp., and Nostoc sp. that microwave treatment is one of the most efficient cell disruption methods and unlike other methods, gives same efficiency of lipid extraction for different species of algae [55].

\section{Pulsed electric field treatment}

In pulsed electric field method, an external electric field is applied that initiates critical electrical potential charge along cell wall or membrane. Electromechanical compression and electroporation induces tension that leads to the formation of pores in the wall or membrane [56]. The number and size of pores are proportional to pulses and the electric field strength. The electroporation can be either reversible or irreversible [57]. In general, increase in conductivity leads to metabolites/compounds release from the disintegrated cells which in turn increases the temperature. This leads to decreases in the efficiency of cell disruption, and hence, this method is less preferable than other methods for extraction of lipid [43]. Eing et al. have demonstrated that the lipid yield increased 9 times when the algae Auxenochlorella protothecoides was pretreated by pulse electric field method before solvent extraction [58].

\section{Non-mechanical disruption methods}

Non-mechanical cell disruption techniques consume less energy when compared to mechanical methods [59]. The methods are more gentle and specific but are difficult to scale up to industrial levels. Nonmechanical methods include physical methods such as freeze-drying and osmotic shock, and chemical methods like enzymatic cell lysis and treatment with chemical agents which involve the permeabilization of cell wall by binding with specific cell wall components. Vogels et al. have demonstrated that combining non-mechanical pretreatment methods like enzyme lysis or heat treatment with other mechanical techniques increased the cell wall disruption efficiency [60].

\section{PHYSICAL DISRUPTION METHODS}

\section{Freeze-drying method}

Freeze-drying makes lipid extraction from algal biomass easier [27]. It ensures that there is no loss of lipids, as they are volatile due to evaporation [61]. In this method, the wet biomass is frozen at $-84^{\circ} \mathrm{C}$ under vacuum to crystalize the intracellular water [62]. After freeze-drying, cell can be directly lysed by allowing the ice crystals to expand by thawing. It can be combined with other methods like grinding ultrasonication or microwave to increase the yield efficiency [63]. If the cells are freeze-dried before bead milling, lipid recovery is more due to enhanced specific area and reduced diffusion gradient [64]. Although this method helps in increasing the efficiency, it is very expensive and has high energy consumption.

\section{Manual grinding}

Manual grinding could be performed in different methods. The first method includes harvesting of microalgae sample into a ceramic mortar, followed by the addition of liquid nitrogen and allowing the sample to thaw and then grounded by a pestle. The second method includes addition of Quartz sand to the sample and grounded directly. The third method includes drying the sample at $60^{\circ} \mathrm{C}$ for $7-8 \mathrm{~h}$ and grounded with Quartz sand [9].

\section{CHEMICAL METHOD}

\section{Sulfuric acid treatment}

Pretreatment of algal biomass for lipid extraction can be performed by sulfuric acid treatment. It is carried out by mixing the concentrated sulfuric acid (3-8\%) with the algal culture and autoclaving at high temperature $\left(120^{\circ} \mathrm{C}-160^{\circ} \mathrm{C}\right)$ for $15-45 \mathrm{~min}$. This type of acid treatment helps in the hydrolysis of polysaccharide carrageenan layer by chain depolymerization and hydrolysis of sulfate moiety [65]. Experiments conducted by Halim et al. suggests that the relative concentration of lysed cell is more when treated with high volume of concentrated sulfuric acid followed by thermal treatment at high temperature [66]. Although this technique has good efficiency and low energy requirement, it is not widely used as there are high chances of product degradation due to the harsh conditions.

\section{Enzymatic method}

One of the most commonly used alternatives for mechanical disruption method is enzymatic lysis. This technique is specific for each microorganism to be lysed and helps in release of specific product [67]. Algal cell walls are strong and stable due to the presence of polysaccharides such as cellulose and hemicellulose. Lysing these cells with mechanical methods is energy intensive and use of enzymes lowers energy requirement [68]. Membranes of the lipid sac are also made of phospholipids. Thus, the common enzymes used for algal cell wall disruption are cellulase and lipase [69].

Cellulose $\stackrel{\text { Cellulase }}{\longrightarrow}$ Glucose

Phospholipid $\stackrel{\text { Lipase }}{\longrightarrow}$ Glycerol

Treatment of $C$. vulgaris with lysozyme and cellulase resulted in lipid concentration of $22 \%$ and $24 \%$, respectively, and had the highest 
efficiency among $>$ all enzymatic treatment (Zheng et al.) [9]. Algal cell wall is made of many complex layers and lysis of all these layers with just cellulase and lipase is not possible. Thus, a mixture of crude enzymes from sources like fungi is required for better efficiency. Like other nonmechanical method, this method can be used either independently or as a pretreatment step for mechanical methods to increase the efficiency and decrease the energy requirements. The major drawback of this method is the unavailability of the large quantity of enzymes required for industrial scale. Chong et al. reported that employment of alkaline pretreatment followed by enzymatic treatment resulted in $90 \%$ lipid extraction from Nannochloropsis sp. [70]. Lipid recovery of $92.6 \%$ was obtained when the enzymatic disruption technique was carried out in combination with mechanical methods (high-pressure homogenization) [71].

\section{CONCLUSION}

Different cell wall disruption techniques were found to be efficient for microalgae and macroalgae. Cell disruption efficiency toward extraction of lipid varies according to the method employed and species. Microwave method and pulsed electronic field method were found to be the most suitable techniques. For the techniques to be feasible, the operating costs and energy consumption should be optimized to ultimately fulfill the major goal of superior quality products and their easy recovery. In-depth research and development of new techniques are required to further improve the cell disruption of the algal cell wall for the enhanced recovery of lipids.

\section{CONFLICTS OF INTERESTS}

The authors declare that there is no conflict of interests regarding the publication of this paper.

\section{AUTHORS CONTRIBUTION}

The authors contributed equally to this work.

\section{REFERENCES}

1. Patil V, Tran KQ, Giselrød HR. Towards sustainable production of biofuels from microalgae. Int J Mol Sci 2008;9:1188-95.

2. Bajhaiya A, Mandotra S, Suseela M, Toppo K, Ranade S. Algal biodiesel: The next generation biofuel for India. Asian J Exp Biol Sci 2010;1:728-39.

3. Khan O, Khan ME, Kumar A, Kumar S. Study on some advanced techniques to produce biodiesel from non-edible oils. Int J Adv Res Innov 2017;5:34-8.

4. Sunil K, Avneesh P, Kunal M. Screening and growth kinetics studies of wild chlorophycean fresh water microalgal species for biomass and biofuel application. Int J Pharm Pharm Sci 2014;7:312-21.

5. Sukahara KT, Awayama SS. Liquid fuel production using microalgae. J Jpn Pet Inst 2005;48:251-9.

6. Saldivar RP. Algae biofuels production processes, carbon dioxide fixation and biorefinery concept. J Pet Environ Biotechnol 2014;5:184.

7. Wang H, Liu G, Ruan R, Liu Y. Biofuel from microalgae: Current status, opportunity and challenge. Proc Int Conf Mater Environ Eng 2014;66:1388-1403.

8. Zemke-White WL,Clements KD, Harris PJ. Acid lysis of macroalgae by marine herbivorous fishes: Effects of acid $\mathrm{pH}$ on cell wall porosity. J Exp Mar Bio Ecol 2000;245:57-68.

9. Zheng H, Yin J, Gao Z, Huang H, Ji X, Dou C, et al. Disruption of chlorella vulgaris cells for the release of biodiesel-producing lipids: A comparison of grinding, ultrasonication, bead milling, enzymatic lysis, and microwaves. Appl Biochem Biotechnol 2011;164:1215-24.

10. Northcote DH, Goulding KJ, Horne RW. The chemical composition and structure of the cell wall of chlorella pyrenoidosa. Biochem $\mathrm{J}$ 1958;70:391-7.

11. Scott SA, Davey MP, Dennis JS, Horst I, Howe CJ, Lea-Smith DJ, et al. Biodiesel from algae: Challenges and prospects. Curr Opin Biotechnol 2010;21:277-86.

12. Demirbas A. Importance of biodiesel as transportation fuel. Energy Policy 2007;35:4661-70.

13. Campbell MN. Biodiesel : Algae as a renewable source for liquid fuel. Guelph Eng J 2008;1:2-7.

14. Gong Y, Jiang M. Biodiesel production with microalgae as feedstock:
From strains to biodiesel. Biotechnol Lett 2011;33:1269-84.

15. Chisti Y. Biodiesel from microalgae beats bioethanol. Trends Biotechnol 2008;26:126-31.

16. Roessler PG, Brown LM, Dunahay TG, Heacox DA, Jarvis EE, Schneider JC, et al. Genetic engineering approaches for enhanced production of biodiesel fuel from microalgae. Enzym Convers Biomass Fuels Prod 1994;566:255-70.

17. Chisti Y, Moo-Young M. Disruption of microbial cells for intracellular products. Enzym Microb Technol 1986;8:194-204.

18. Kumar RR, Rao PH, Arumugam M. Lipid extraction methods from microalgae: A comprehensive review. Front Energy Res 2015;2:61.

19. Lee SJ, Yoon BD, Oh HM. Rapid method for the determination of lipid from the green alga Botryococcus braunii. Biotechnol Tech 1998;12:553-6.

20. Geciova J, Bury D, Jelen P. Methods for disruption of microbial cells for potential use in the dairy industry - A review. Int Dairy $\mathrm{J}$ 2002; $12: 541-53$

21. Doucha J, Lívanský K. Influence of processing parameters on disintegration of chlorella cells in various types of homogenizers. Appl Microbiol Biotechnol 2008;81:431-40.

22. Greenwell HC, Laurens LM, Shields RJ, Lovitt RW, Flynn KJ. Placing microalgae on the biofuels priority list: A review of the technological challenges. J R Soc Interface 2010;7:703-26.

23. Postma PR, Suarez-Garcia E, Safi C, onathana KY, Olivieri G, Barbosa MJ, et al. Bioresource technology energy efficient bead milling of microalgae : Effect of bead size on disintegration and release of proteins and carbohydrates. Bioresour Technol 2017;224:670-9.

24. Hopkins TR. Physical and chemical cell disruption for the recovery of intracellular proteins. Bioprocess Technol 1991;12:57-83.

25. Miranda JR, Passarinho PC, Gouveia L. Bioethanol production from scenedesmus obliquus sugars: The influence of photobioreactors and culture conditions on biomass production. Appl Microbiol Biotechnol 2012;96:555-64.

26. Krisnangkura K. Simple method for estimation of cetane index of vegetable oil methyl esters. J Am Oil Chem Soc 1986;63:552-3.

27. Munir N, Sharif N, Shagufta N, Saleem F, Manzoor F. Harvesting and processing of microalgae biomass fractions for biodiesel production (a review). Sci Tech Dev 2013;32:235-43.

28. Kim J, Yoo G, Lee H, Lim J, Kim K, Kim CW, et al. Methods of downstream processing for the production of biodiesel from microalgae. Biotechnol Adv 2013;31:862-76.

29. Shen Y, Pei Z, Yuan W, Mao E. Effect of nitrogen and extraction method on algae lipid yield. Int J Agric Biol Eng 2009;2:51-7.

30. Petrier C, Jiang Y, Lamy MF. Ultrasound and environment: Sonochemical destruction of chloroaromatic derivatives. Environ Sci Technol 1998;32:1316-8.

31. Günerken E, D’Hondt E, Eppink MH, Garcia-Gonzalez L, Elst K, Wijffels RH, et al. Cell disruption for microalgae biorefineries. Biotechnol Adv 2015;33:243-60.

32. Lee AK, Lewis DM, Ashman PJ. Disruption of microalgal cells for the extraction of lipids for biofuels: Processes and specific energy requirements. Biomass Bioenergy 2012;46:101.

33. Spiden EM, Yap BH, Hill DR, Kentish SE, Scales PJ, Martin GJ, et al. Quantitative evaluation of the ease of rupture of industrially promising microalgae by high pressure homogenization. Bioresour Technol 2013;140:165-71.

34. Olmstead IL, Hill DR, Dias DA, Jayasinghe NS, Callahan DL, Kentish SE, et al. A quantitative analysis of microalgal lipids for optimization of biodiesel and omega-3 production. Biotechnol Bioeng 2013;110:2096-104.

35. Yap BH, Crawford SA, Dumsday GJ, Scales PJ, Martin GJ. A mechanistic study of algal cell disruption and its effect on lipid recovery by solvent extraction. Algal Res 2014;5:112-20.

36. Halim R, Gladman B, Danquah MK, Webley PA. Oil extraction from microalgae for biodiesel production. Bioresour Technol 2011;102:178-85.

37. Samarasinghe N, Fernando S, Lacey R, Faulkner WB. Algal cell rupture using high pressure homogenization as a prelude to oil extraction. Renew Energy 2012;48:300-8

38. Balasubramanian RK, Doan TT, Obbard JP. Factors affecting cellular lipid extraction from marine microalgae. Chem Eng J 2013;215:929-36.

39. Wang G, Wang T. Characterization of lipid components in two microalgae for biofuel application. J Am Oil Chem Soc 2012;89:135-43.

40. Chemat F, Zill-e-Huma, Khan MK. Applications of ultrasound in food technology: Processing, preservation and extraction. Ultrason Sonochem 2011;18:813-35.

41. Suslick KS, Flannigan DJ. Inside a collapsing bubble: 
Sonoluminescence and the conditions during cavitation. Annu Rev Phys Chem 2008;59:659-83.

42. Pal A, Verma A, Kachhwaha SS, Maji S. Biodiesel production through hydrodynamic cavitation and performance testing. Renew Energy 2010;35:619-24.

43. Joannes C, Sipaut CS, Dayou J, Yasir SM, Mansa RF. The potential of using pulsed electric field (PEF) technology as the cell disruption method to extract lipid from microalgae for biodiesel production. Int $\mathrm{J}$ Renew Energy Res 2015;5:598-21.

44. Brujan EA, Nahen K, Schmidt P, Vogel A. Dynamics of laserinduced cavitation bubbles near an elastic boundary. Fluid Mech 2001;433:251-81.

45. Engler CR. Disruption of microbial cells. Princ Biotechnol Eng Consid 1985;2:305-24.

46. Halim R, Hosikian A, Lim S, Danquah MK. Chlorophyll extraction from microalgae: A review on the process engineering aspects. Int $\mathrm{J}$ Chem Eng 2010;2010:1-11.

47. Adam F, Abert-Vian M, Peltier G, Chemat F. "Solvent-free" ultrasoundassisted extraction of lipids from fresh microalgae cells: A green, clean and scalable process. Bioresour Technol 2012;114:457-65.

48. Mason TJ, Lorimer JP, Bates DM, Zhao Y. Dosimetry in sonochemistry: The use of aqueous terephthalate ion as a fluorescence monitor. Ultrason Sonochem 1994;1:S91-5.

49. Krehbiel JD, Schideman LC, King DA, Freund JB. Algal cell disruption using microbubbles to localize ultrasonic energy. Bioresour Technol 2014;173:448-51.

50. Sheng J, Vannela R, Rittmann BE. Disruption of synechocystis PCC 6803 for lipid extraction. Water Sci Technol 2012;65:567-73.

51. Pan X, Niu G, Liu H. Comparison of microwave-assisted extraction and conventional extraction techniques for the extraction of tanshinones from Salvia miltiorrhiza bunge. Biochem Eng J 2002;12:71-7.

52. Terigar BG, Balasubramanian S, Boldor D, Xu Z, Lima M, Sabliov CM, et al. Continuous microwave-assisted isoflavone extraction system: Design and performance evaluation. Bioresour Technol 2010;101:2466-71

53. Balasubramanian S, Allen JD, Kanitkar A, Boldor D. Oil extraction from scenedesmus obliquus using a continuous microwave system Design, optimization, and quality characterization. Bioresour Technol 2011;102:3396-403.

54. Wahidin S, Idris A, Shaleh SR. Rapid biodiesel production using wet microalgae via microwave irradiation. Energy Convers Manag 2014;84:227-33.

55. Prabakaran P, Ravindran AD. A comparative study on effective cell disruption methods for lipid extraction from microalgae. Lett Appl Microbiol 2011;53:150-4.

56. Qin S, Timoshkin IV, Michelle M, Wilson MP, MacGregor SJ, Given MJ, et al. Pulsed electric field treatment of microalgae: Inactivation tendencies and energy consumption. IEEE Trans Plasma Sci 2014;42:3191-6

57. Alexandra D, Fernandes S. Assessment of a Pulsed Electric Field based Treatment for Marine Microalgae Cell Disruption. Diss. Master Dissertation in Biological Engineering, Instituto Superior Técnico, Universidade de Lisboa; 2015.

58. Eing C, Goettel M, Straessner R, Gusbeth C, Frey W. Pulsed electric field treatment of microalgae - Benefits for microalgae biomass processing. IEEE Trans Plasma Sci 2013;41:2901-7.

59. Klimek-Ochab M, Brzezińska-Rodak M, Zymańczyk-Duda E, Lejczak B, Kafarski P. Comparative study of fungal cell disruption - scope and limitations of the methods. Folia Microbiol (Praha) 2011;56:469-75.

60. Vogels G, Kula MR. Combination of enzymatic and/or thermal pretreatment with mechanical cell disintegration. Chem Eng Sci 1992;47:123-31.

61. Pourmortazavi SM, Hajimirsadeghi SS. Supercritical fluid extraction in plant essential and volatile oil analysis. J Chromatogr A 2007;1163:2-4.

62. Guldhe A, Singh B, Rawat I, Ramluckan K, Bux F. Efficacy of drying and cell disruption techniques on lipid recovery from microalgae for biodiesel production. Fuel 2014;128:46-52.

63. Prakash P, Raja SN. Evaluation of protein release rate frommycoprotien - Fusarium venenatum by cell disruption method. Int J Pharm Pharm Sci 2014;6:491-3.

64. Halim R, Rupasinghe TW, Tull DL, Webley PA. Mechanical cell disruption for lipid extraction from microalgal biomass. Bioresour Technol 2013;140:53-63.

65. Daroch M, Geng S, Wang G. Recent advances in liquid biofuel production from algal feedstocks. Appl Energy 2013;102:1371-81.

66. Halim R, Danquah MK, Webley PA. Extraction of oil from microalgae for biodiesel production: A review. Biotechnol Adv 2012;30:709-32.

67. Andrews BA, Asenjo JA. Enzymatic lysis and disruption of microbial cells. Trends Biotechnol 1987;5:273-7.

68. Vanthoor-Koopmans M, Wijffels RH, Barbosa MJ, Eppink MH. Biorefinery of microalgae for food and fuel. Bioresour Technol 2013;135:142-9

69. Sander K, Murthy G. Enzymatic degradation of microalgal cell walls. ASABE Anu Int Meet 2009;300:12.

70. Wu C, Xiao Y, Lin W, Li J, Zhang S, Zhu J, et al. Aqueous enzymatic process for cell wall degradation and lipid extraction from nannochloropsis sp. Bioresour Technol 2017;223:312-6.

71. Wang D, Li Y, Hu X, Su W, Zhong M. Combined enzymatic and mechanical cell disruption and lipid extraction of green alga neochloris oleoabundans. Int J Mol Sci 2015;16:7707-22.

72. Koberg M, Cohen M, Ben-amotz A, Gedanken A. Bioresource technology bio-diesel production directly from the microalgae biomass of nannochloropsis by microwave and ultrasound radiation. Bioresour Technol 2011;102:4265-9

73. Dhar DW, Saha S. Cell disruption methods for improving lipid extraction efficiency in unicellular microalgae. Eng Life Sci 2015;15:443-7.

74. Zbinden MD, Sturm BS, Nord RD, Carey WJ, Moore D, Shinogle H, et al. Pulsed electric field (PEF) as an intensification pretreatment for greener solvent lipid extraction from microalgae. Biotechnol Bioeng 2013;110:1605-15. 